\title{
Calculation of Prime Cost of Animal Production by Means of ABC Method
}

\author{
Pavlyuchenko T.N. \\ Accounting and Audit Department \\ Emperor Peter the Great State Agrarian University \\ Voronezh, Russia \\ Pavlychenko_tn@mail.ru
}

\author{
Kosteva N.N. \\ Accounting and Audit Department \\ Emperor Peter the Great State Agrarian University \\ Voronezh, Russia \\ natallia.79@mail.ru
}

\begin{abstract}
One of the most important problems is a timely and accurate taking into account the expenditures and production outcome. The following things depend on the quality of this accounting information: cost formation, compensation for costs, the income of the enterprise and the quality of the released production improvement.

In this connection the problem of expenditures management accounting system of creation in agriculture is extremely urgent for native scientists.

The article presents the methodologies of prime cost calculation of animal production by means of traditional method and $\mathrm{ABC}$ method and also studies perspective introductions of $\mathrm{ABC}$ method into the practice of agricultural enterprises.

The carried out research helped to make the following conclusion: during ABC method use some difficulties can appear, which are connected with the groups determination of processes of production, expenditures drivers. As this system is not widely used and there are no created methodical recommendations, it can lead to incorrect processes and expenditures drivers distribution, distortion of prime cost of the production. However, in case of a competent approach, this method use would lead to more precise result achievement concerning the expenses and it would help the directors to make more reasonable managerial decisions.
\end{abstract}

Keywords-management accounting; prime cost; expenditures; $A B C$ method; calculation; methods of expenditures accounting

\section{INTRODUCTION}

Forming the system of management accounting at the enterprise provides competent estimation of current state, the dynamics of development determination and also helps to create the complex of events, which provide the effectiveness increase of the realized activity, based on timely strategic decisions making.

It is impossible to state which of the existing methods of expenditures calculation and prime cost determination is the most accurate and optimal for use. It is necessary to take into consideration the fact, that for managerial decisions making the most effective is considered to be accountancy prepared on the basis of marginal analysis of prime cost calculation.

\section{LITERATURE REVIEW}

Konstantinov V.A. (Konstantinov, V.A. (2013)), Shefer A.A. (Sheffer, A.A. (2015)), Usatova L.V. (Usatova, L.V. (2008)), the supporters of marginal gain and prime cost calculation, claim that constant costs distribution is realized on absolutely voluntary basis, so such information can't be used during management decisions making. The method of total costs absorption doesn't contain useful information for management staff, it can even disorient.

Sorokina V.V. (Sorokina, V.V. (2017)), Bengardt M.V. (Bengardt, M.V. (2011)) have another point of view. They prefer the method of production cost calculation. The authors say that production is impossible without constant production expenditures, which are unprofitable in terms of the main product, however during prime cost calculation one shouldn't ignore them.

One of the most interesting directions during prime cost calculation of the product is $\mathrm{ABC}$ method use. The method is based on taking into account the expenditures according to the functions. The founders of this method are Cooper R. and Kaplan R.

The distinctive feature of the method is overhead expenses distribution not according to the kinds of the produced production, but according to the fulfilled during production actions. It was the reason for the name of the method - Activity Based Costing.

Traditional approach to prime cost calculation in the system of accounting means that final product should include constant and alternating expenses.

$\mathrm{ABC}$ method takes into account the usefulness of information for making decisions by the directors. Cost driver is the fulfilled action, which presents the definite fulfilled function, concerning the definite kind of activity. 
First of all, the kinds of activity, which increase the

ABC method helps to find not connected with the volume of production base for overhead expenses distribution.

However, at agricultural enterprises this kind of accounting wasn't widely used. It is connected with the fact that there are no general created recommendations concerning management accounting introduction into agrarian sector.

The problems of management accounting formation at enterprises of agrarian sector are studied in scientific works of the following scientists: M.A. Vakhrushina (Vakhrushina, M.A. (2012)), V.B.Ivashkevich (Ivashkevich, V.B. (2011)), N.N. Karzaeva (Karzaeva, N.N. (2014)), E.I.Kostyukova (Kostyukova, E.I. (2014), (2015)), V.G. Shirobokov (Shirobokov, V.G. (2010)).

\section{RESEARCH METHODOLOGY}

As it was mentioned above, enterprises, including agrarian enterprises, face great volume of overhead expenses, which can be connected with the following:

- material values movement;

- resources provision into production;

- the quality of production provision;

- consumers' needs satisfaction and etc.

$\mathrm{ABC}$ method helps to avoid mistakes, connected with traditional distribution of indirect expenses proportionally to general for all subjects of economic activity base (labor and wok time inputs, the volume of productive production, the volume of receipts from sale). More progressive technologies application in production provides the part of direct costs decrease in terms of simultaneous increase of indirect costs. An integrated algorithm of indirect costs connection with the prime cost distorts real state, creating the effect of high profitability according to the products, which in reality are not the one.

Prime cost of production calculation by means of the traditional method and $\mathrm{ABC}$ method was realized on the materials of public corporation "Yuzhnoe" of Rossoshansk district of Voronezh region. This enterprise is a great owner of Rossoshansk district of Voronezh region, which specializes in milk production.

The main difference of $\mathrm{ABC}$ method is productive overhead expenses accumulation not at districts (operations), but on the process (subdivisions), with further distribution according to the kinds of productions, used in these operations.

ABC-Method use in public corporation "Yuzhnoe" provides the use of expenditures driver according to each productive process. Processes, not connected with directly with the volumes of production, include expenses connected with equipment use, production transportation to the places of

storage, transport repair, amortization of equipment, control over quality of production. added value of production, are identified. For example, in the analyzed organization, which specializes on animal production, the following kinds of activity are defined: labor of the workers, buying feed-stuff and materials, equipment setting and repair, production gathering, the quality of production check.

Secondly, cost drivers for each kind of activity are defined according to the content and quantity.

The most difficult and responsible moment is complex operations decomposition into the fulfilled actions, which give an opportunity to use different cost drivers for the components of the fulfilled action. Manyaeva V.A. (Manyaeva V.A. (2011)) defines cost drivers as follows: the number of material resources supply, the number of products quality checks, number of equipment tune-ups and others.

TABLE I. CORRELATION OF EXPENSES AND THEIR DRIVERS IN ANIMAL HUSBANDRY

\begin{tabular}{|c|c|}
\hline Expenditures & Cost drivers \\
\hline Feed-stuff & $\begin{array}{l}\text { Transportation to the farm; giving animals } \\
\text { food }\end{array}$ \\
\hline Wage with allocations & $\begin{array}{l}\text { Cleaning; enclosures charging ; food giving; } \\
\text { veterinary inspections; }\end{array}$ \\
\hline $\begin{array}{l}\text { Means of animals } \\
\text { protection }\end{array}$ & $\begin{array}{lll}\begin{array}{l}\text { Number of } \\
\text { inspection }\end{array} & \text { vaccinations; veterinary } \\
\end{array}$ \\
\hline Fixed assets content & $\begin{array}{l}\text { Amortization; equipment adjustment; } \\
\text { equipment checkout; equipment support; }\end{array}$ \\
\hline Works and services & transportation; ventilation; \\
\hline $\begin{array}{l}\text { Production organization } \\
\text { and control }\end{array}$ & $\begin{array}{l}\text { Recalculation of animals; quality of products } \\
\text { control; }\end{array}$ \\
\hline $\begin{array}{l}\text { Expenses connected with } \\
\text { animals } \\
\text { animals }\end{array}$ & expertise; utilization; \\
\hline Other costs & $\begin{array}{l}\text { rent; functional specialists' consultations; } \\
\text { insurance }\end{array}$ \\
\hline
\end{tabular}

\section{RESULTS}

The created system of drivers helps to define the reasons for overhead costs appearance, their cost estimation and also define the moments for managerial decisions making. Drivers, as the cost drivers, increase the level of validity of the made managerial decisions, as they answer several questions: Which resources were used in production and Which working operations were used during this process?

TABLE II. EXPENDITURES GROUPING ACCORDING TO COST DRIVERS

\begin{tabular}{|l|l|l|l|l|l|}
\hline $\begin{array}{l}\text { Costs } \\
\text { accumulation } \\
\text { according to } \\
\text { processes }\end{array}$ & Cost driver & $\begin{array}{l}\text { Process } \\
\text { expenditure } \\
\text { s, rubles }\end{array}$ & Milk & $\begin{array}{l}\text { Mass } \\
\text { increas } \\
\mathrm{e}\end{array}$ & Total \\
\hline $\begin{array}{l}\text { Equipment } \\
\text { amortization }\end{array}$ & $\begin{array}{l}\text { Number of } \\
\text { main means } \\
\text { use }\end{array}$ & 6986917 & 240 & 149 & 389 \\
\hline $\begin{array}{l}\text { Transportation } \\
\text { butches of }\end{array}$ & $\begin{array}{l}\text { Number } \\
\text { bater }\end{array}$ & 3189000 & 67 & 45 & 112 \\
\hline $\begin{array}{l}\text { Materials } \\
\text { transportation } \\
\text { to the farm }\end{array}$ & $\begin{array}{l}\text { Number of } \\
\text { deliveries }\end{array}$ & 2111245 & 98 & 14 & 112 \\
\hline
\end{tabular}




\section{CONCLUSION}

During the methodology of prime cost calculation change of the main dairy herd it was possible to define overhead expenses on each kind of product production, which is difficult to get in terms of some other method use. Knowing the volume of overhead expenses according to each of the processes, it is possible to control them and find out the reason of over-expenditure.

In case of a competent approach, ABS method use would lead to more precise result achievement concerning the expenses and it would help to get great volume of information for managerial decisions making, constant production, business processes development and also gives an opportunity to manage overhead expenses.

\section{References}

base for the rate calculation for each component of the costs.

TABLE III. RATES OF DRIVERS CALCULATION ACCORDING TO PROCESSES

\begin{tabular}{|l|l|l|l|}
\hline $\begin{array}{l}\text { Costs accumulation } \\
\text { according to processes }\end{array}$ & $\begin{array}{l}\text { Common } \\
\text { cost } \\
\text { according to } \\
\text { process, } \\
\text { thous. rubles. }\end{array}$ & $\begin{array}{l}\text { Number of } \\
\text { parameters } \\
\text { according to } \\
\text { each kind }\end{array}$ & $\begin{array}{l}\text { Driver cost, } \\
\text { thous. rubles. }\end{array}$ \\
\hline Equipment amortization & 6986.92 & 389 & 17.96 \\
\hline Transportation & 3189 & 112 & 28.47 \\
\hline $\begin{array}{l}\text { Materials transportation } \\
\text { to the farm }\end{array}$ & 2111.25 & 112 & 18.85 \\
\hline Equipment adjustment & 8184.2 & 278 & 29.44 \\
\hline $\begin{array}{l}\text { Control over products } \\
\text { quality }\end{array}$ & 1245.78 & 35 & 35.59 \\
\hline
\end{tabular}

At the $5^{\text {th }}$ stage costs are distributed for production management, in terms of preliminary set amount of cost drivers for each unit of this kind of product.

At the final stage calculation matrix of production cost is made, formed according to $\mathrm{ABC}$ method. For each kind of product costs are calculated as the product of the driver rate according to each characteristic into the number of this characteristic demonstration (table IV).

TABLE IV. PRIME COST OF ANIMAL PRODUCTION CALCULATION BY MEANS OF ABC METHOD

\begin{tabular}{|l|l|l|l|}
\hline Expenses & Milk & $\begin{array}{l}\text { Mass } \\
\text { increase }\end{array}$ & Total \\
\hline $\begin{array}{l}\text { Direct outlays on materials, } \\
\text { thous. rubles }\end{array}$ & 27862.24 & 15025.19 & 42887.43 \\
\hline $\begin{array}{l}\text { Outlays on wages, thous. } \\
\text { rubles }\end{array}$ & 16586.46 & 6816.12 & 23402.58 \\
\hline Production overhead expenses, thous. rubles \\
\hline Equipment amortization & 4310.69 & 2676.22 & 6986.92 \\
\hline Transportation & 1907.71 & 1281.30 & 3189.00 \\
\hline $\begin{array}{l}\text { Materials transportation to the } \\
\text { farm }\end{array}$ & 1847.34 & 263.91 & 2111.25 \\
\hline Equipment adjustment & 6623.90 & 1560.30 & 8184.20 \\
\hline Control over products quality & 1067.82 & 177.97 & 1245.78 \\
\hline Total volume of costs & 60980.26 & 27026.90 & 88007.16 \\
\hline Prime cost rub./t & 1829.81 & 14586.04 & $\mathrm{x}$ \\
\hline
\end{tabular}

[1] Bengardt M.V. Prime cost of animal production calculation. Accounting in agriculture. 4, 33 .

[2] Vakhrushina M.A. Accounting: textbook. Moscow, National education.

[3] Deryabina I.G. ABC-model of prime cost of agricultural product calculation. Scientific society of students of the XXI century. Economic sciences: prime cost on the material of the XIX International student scientific-practical conference. Novosibirsk, SibAK.

[4] Ivashkevich V.B. Accounting. The $2^{\text {nd }}$ edition, transferred and added. Moscow, Master.

[5] Karzaeva N.N. Accounting of costs in agriculture. 10, 5.

[6] Kosmenkova S.V. The peculiarities of accounting of production costs in terms of different variants of outcome from dairy breeding products. Everything for an accountant. 3,2.

[7] Konsrtantinov V.A. Algorithm of Activity Based Costing (ABC) method realization at Russian enterprises. Managerial accounting. 8,19 .

[8] Kostyukova E.I. Experience of $\mathrm{ABC}$ method introduction into accounting practice of agricultural organizations. International accounting. 37,2.

[9] Kostyukova E.I. Accounting: educational manual. Moscow, KnoRus.

[10] Kurt Heisinger (Sierra College), Joe Hoyle (University of Richmond) Managerial Accounting.139.

[11] Mandzhieva D.V. Methodical instruments development of managerial costs accounting in animal husbandry on the basis of ABC-Method. Questions of modern science and practice. University named after V.I. Vernadskiy (since 169-177) Tambov FSBEE HE "Tambov State Technical University"

[12] Manyaeva V.A. ABC-method - information system of strategic managerial expenditure accounting according to the kinds of activity. International accounting. 2, 35.

[13] Sorokina V.V. Modern approaches to productive prime cost calculation. Azimuth of scientific research works: economics and management. Tolyatti "Institute of the directed professional education". vol. 6, pp. 220-222.

[14] Usatova L.V. Mechanism of ABS-method use in accountinganalytical system of costs for effective control over prime cost of the released products. Management accounting. 10, 36 .

[15] 15.Sheffer A.A. Functional accounting of costs (ABC method). Young people of Siberia - science of Russia. Materials of the International scientific-practical conference. Krasnoyarsk NOU VPO SIBUP. 366-369.

[16] Alexsandr S. Kuznetsov. Russian Professor's meeting. Russian Journal of Physical Education and Sport. 2019, 14(1), pp. 17-22. DOI: $10.14526 / 2070-4798-2019-14-1-18-24$

[17] Shirobokov V.G. Accounting in organizations of APK. Moscow, Finance and Statistics 